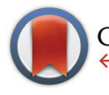

CrossMark

Cite this: Dalton Trans., 2016, 45 19230

Received 3rd November 2016, Accepted 14th November 2016

DOI: $10.1039 / c 6 d t 04206 f$

www.rsc.org/dalton

\section{Indirect synthesis of a pair of formal methane activation products at a phosphane/borane frustrated Lewis pair $\dagger$}

\author{
Silke Frömel, ${ }^{a}$ Constantin G. Daniliuc, $\star^{a}$ Christoph Bannwarth, $\S^{\mathrm{b}}$ Stefan Grimme, $\S^{\mathrm{b}}$ \\ Kathrin Bussmann, ${ }^{a}$ Gerald Kehr ${ }^{a}$ and Gerhard Erker*a
}

The regioisomeric formal $\mathrm{Mes}_{2} \mathrm{PCH}_{2} \mathrm{CH}_{2} \mathrm{~B}\left(\mathrm{C}_{6} \mathrm{~F}_{5}\right)_{2}$ FLP methane splitting products $\mathrm{Mes}_{2} \mathrm{P}(\mathrm{H}) \mathrm{CH}_{2} \mathrm{CH}_{2} \mathrm{~B}\left(\mathrm{CH}_{3}\right)\left(\mathrm{C}_{6} \mathrm{~F}_{5}\right)_{2}$ and $\mathrm{Mes}_{2} \mathrm{P}\left(\mathrm{CH}_{3}\right)$ $\mathrm{CH}_{2} \mathrm{CH}_{2} \mathrm{~B}(\mathrm{H})\left(\mathrm{C}_{6} \mathrm{~F}_{5}\right)_{2}$ were produced by indirect stepwise reactions. They were stable at $60{ }^{\circ} \mathrm{C}$ and were both characterized by X-ray diffraction. A DFT analysis revealed that their formation from the FLP and $\mathrm{CH}_{4}$ would be endergonic by +6.9 and $+3.6 \mathrm{kcal} \mathrm{mol}^{-1}$, respectively, and it indicated that methane elimination from the zwitterionic products is kinetically hindered by barriers of 54.0 and $72.3 \mathrm{kcal} \mathrm{mol}^{-1}$, respectively.

Frustrated Lewis pairs (FLPs) can effect a number of remarkable reactions. ${ }^{1,2}$ Most noteworthy is the ability of many FLPs to split dihydrogen heterolytically in a metal-free situation and, consequently, to serve as efficient main-group element derived hydrogenation catalysts for a variety of organic (or even organometallic) substrates. ${ }^{3}$ In addition, frustrated Lewis pairs add and sometimes activate a variety of small molecules, among them $\mathrm{CO}, \mathrm{CO}_{2}, \mathrm{SO}_{2}, \mathrm{NO}, \mathrm{N}_{2} \mathrm{O}^{4}$ and they have actively been involved in developing a few new and unprecedented reactions. ${ }^{5,6}$ However, not too much is known about the reaction of FLPs with non-activated $\mathrm{C}-\mathrm{H}$ bonds, ${ }^{7,8}$ especially of the parent saturated hydrocarbon methane. We so far were not able to activate the $\mathrm{CH}_{4}$ molecule by a reaction at a frustrated Lewis pair framework, ${ }^{9}$ but we have now prepared the two possible methane $\mathrm{C}-\mathrm{H}$ activation products at the ethylenebridged intramolecular P/B FLP 1 by an indirect stepwise reaction pathway. From the isolated products we learned about the kinetic stability of the alleged $\mathrm{CH}_{4} / \mathrm{FLP}$ activation products and, in combination with a DFT analysis, about the

\footnotetext{
${ }^{a}$ Organisch-Chemisches Institut, Universität Münster, Corrensstrasse 40, 48149 Münster, Germany. E-mail: erker@uni-muenster.de; Fax: +49-251-8336503 ${ }^{b}$ Mulliken Center for Theoretical Chemistry, Institut für Physikalische und Theoretische Chemie, Universität Bonn, Beringstr. 4, D-53115 Bonn, Germany $\dagger$ Electronic supplementary information (ESI) available: The syntheses and characterization of the new compounds and about the DFT calculations. CCDC 1500836-1500838. For ESI and crystallographic data in CIF or other electronic format see DOI: $10.1039 / \mathrm{c} 6 \mathrm{dt} 04206 \mathrm{f}$

\$X-ray crystal structure analysis.

$\S$ Computational chemistry.
}

thermodynamic features of the pair of possible $\mathrm{CH}_{4}+1$ reaction alternatives. These results will briefly be discussed in this account.

We had previously shown that the P/B FLP 1 reacted cleanly with the halogens $\mathrm{Cl}_{2}$ or $\mathrm{Br}_{2}$ to form the respective $[\mathrm{P}] \mathrm{Hal}^{+} /[\mathrm{B}]$ $\mathrm{Hal}^{-}$addition products $\mathbf{2 a}, \mathbf{b} .{ }^{10}$ With $\mathrm{HCl}$ compound $\mathbf{1}$ gave the respective $[\mathrm{P}] \mathrm{H}^{+} /[\mathrm{B}] \mathrm{Cl}^{-}$product $\mathbf{4}^{11}$ and with acyl chlorides the respective ketene addition products 3 [plus the $[\mathrm{P}] \mathrm{H}^{+} /\left[\mathrm{B}^{-} \mathrm{Cl}^{-}\right.$ co-product (4)] were formed. ${ }^{12}$ We extended this series of FLP reactions now by the reaction of $\mathbf{1}$ with methyl iodide which cleanly gave the corresponding $[\mathrm{P}] \mathrm{CH}_{3}{ }^{+} /[\mathrm{B}] \mathrm{I}^{-}$product 5 , which we isolated in $87 \%$ yield as a colorless solid (see Scheme 1). We used compound $\mathbf{5}$ as the starting material for the synthesis of the respective $[\mathrm{P}] \mathrm{CH}_{3}{ }^{+} /[\mathrm{B}] \mathrm{H}^{-}$product 6 , one of the two formal $\mathrm{CH}_{4} / \mathrm{FLP}$ splitting products.

Compound 5 shows the core heteroatom NMR resonances at $\delta-7.4\left({ }^{11} \mathrm{~B}\right)$ and $\delta 26.7\left({ }^{31} \mathrm{P}\right)$, respectively. It features the typical NMR data of the pairs of mesityl groups at phosphorus and $\mathrm{C}_{6} \mathrm{~F}_{5}$ groups at boron and the bridging ethylene unit (for details see the ESI $\dagger$ ). The newly introduced methyl substituent at phosphorus gave rise to a ${ }^{1} \mathrm{H}$ NMR signal at $\delta 2.44\left(\mathrm{~d},{ }^{2} J_{\mathrm{PH}}=\right.$ 12.4 Hz; ${ }^{13} \mathrm{C}: \delta 16.3,{ }^{1} J_{\mathrm{PC}}=53.2 \mathrm{~Hz}$ ). The X-ray crystal structure

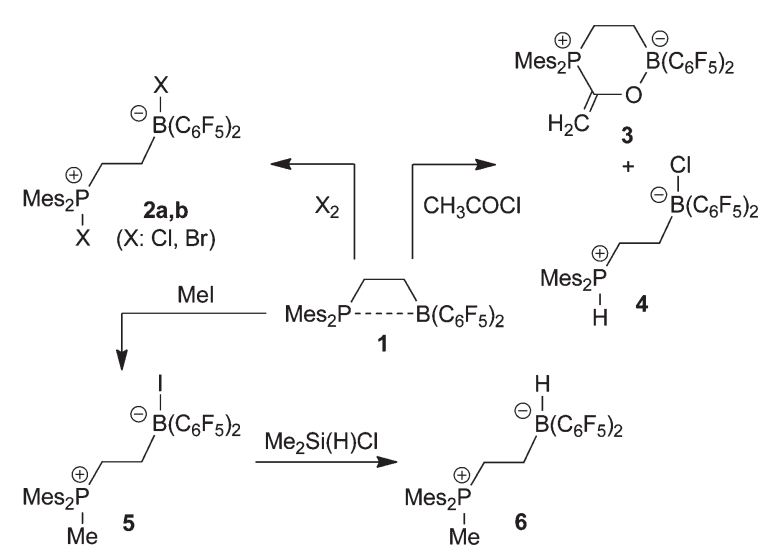

Scheme 1 


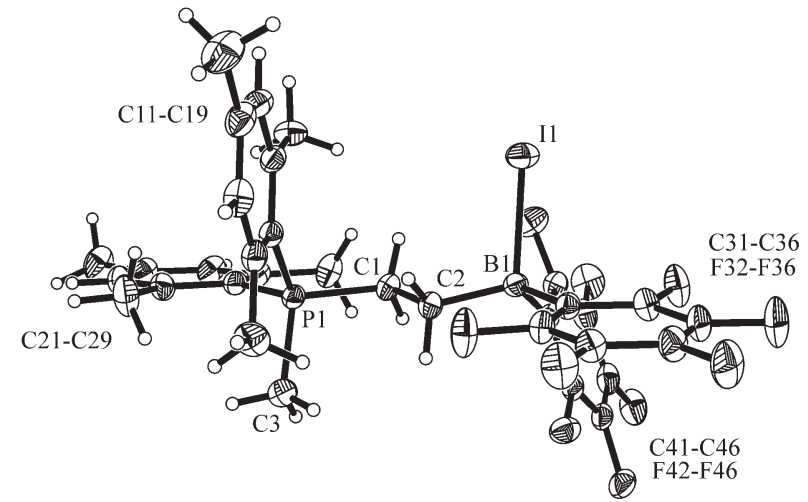

Fig. 1 Molecular structure of compound 5 (thermal ellipsoids are shown at $30 \%$ probability). Selected bond lengths $(\AA \AA)$ and angles $\left({ }^{\circ}\right)$ : P1C3 1.824(3), P1-C1 1.823(3), C1-C2 1.542(4), C2-B1 1.616(4), B1-I1 2.369(3), $\sum \mathrm{B} 1{ }^{\mathrm{CCC}} 337.7, \mathrm{C} 1-\mathrm{P} 1-\mathrm{C} 3$ 103.3(2), C2-B1-I1 106.4(2), P1-C1C2-B1 -169.4(2), $\theta$ C3-P1‥B1-I1 -169.0.

analysis of compound 5 confirmed the attachment of the methyl group at phosphorus and the iodide substituent at boron. Both these heteroatoms show distorted tetrahedral coordination environments. The central P1-C1-C2-B1 unit shows an antiperiplanar conformational geometry (Fig. 1).

The iodide substituent at boron in compound $\mathbf{5}$ was exchanged for hydride by treatment with dimethylchlorosilane. ${ }^{13}$ It was stirred with a $c a .2 .4$ times excess of the silane in dichloromethane solution for $30 \mathrm{~min}$ at r.t. Layering with pentane $\left(-30{ }^{\circ} \mathrm{C}, 6 \mathrm{~d}\right)$ eventually gave the crystalline product 6 , which was isolated in $88 \%$ yield. The X-ray crystal structure analysis confirmed the successful removal of the halide and introduction of hydride at the pseudotetrahedral borate moiety $\left(\sum \mathrm{B} 1^{\mathrm{CCC}} 334.6^{\circ}\right)$ of the zwitterionic compound (see Fig. 2). Again the central core of the molecule shows a slightly distorted antiperiplanar conformation $(\theta$ P1-C1-C2-B1 $\left.161.9(2)^{\circ}\right)$, and the $\mathrm{C} 3-\mathrm{P} 1-\mathrm{C} 1-\mathrm{C} 2$ arrangement is gauche $\left(\theta 72.7(3)^{\circ}\right)$.

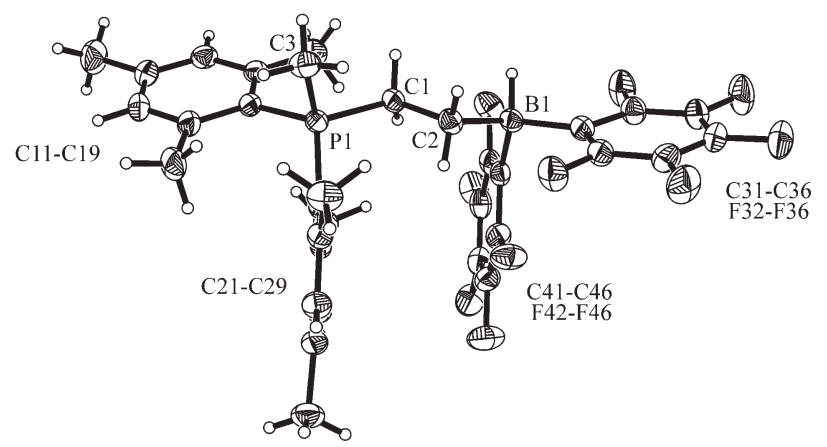

Fig. 2 A projection of the molecular structure of the zwitterionic [P] $\mathrm{CH}_{3}{ }^{+} /[\mathrm{B}] \mathrm{H}^{-}$compound 6 (thermal ellipsoids are shown at $30 \%$ probability). Selected bond lengths (Å) and angles ( ${ }^{\circ}$ ): P1-C3 1.800(3), P1-C1 1.807(3), C1-C2 1.541(4), C2-B1 1.640(4), C1-P1-C3 102.9(2), C1-C2-

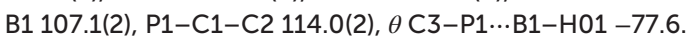

In $\mathrm{d}_{2}$-dichloromethane the presence of the [B]- $\mathrm{H}$ group is confirmed in the ${ }^{11} \mathrm{~B}$ NMR spectrum by the respective resonance at $\delta-19.7\left(\mathrm{~d},{ }^{1} J_{\mathrm{BH}} \sim 90 \mathrm{~Hz}\right)$. The $[\mathrm{P}]-\mathrm{CH}_{3}$ group gives rise to NMR resonances at $\delta 25.8\left({ }^{31} \mathrm{P}\right), 2.39\left({ }^{1} \mathrm{H},{ }^{2} J_{\mathrm{PH}}=12.5 \mathrm{~Hz}\right)$ and $\delta 16.0\left({ }^{13} \mathrm{C},{ }^{1} J_{\mathrm{PC}}=54.3 \mathrm{~Hz}\right)$ and we have monitored the typical NMR features of the $-\mathrm{CH}_{2}-\mathrm{CH}_{2}-$ bridge and the pairs of mesityl groups at phosphorus and $\mathrm{C}_{6} \mathrm{~F}_{5}$ substituents at boron (for details see the $\mathrm{ESI}_{\dagger} \dagger$ ).

We also explored the stepwise formation of the other possible formal FLP methane $\mathrm{C}-\mathrm{H}$ splitting product, namely the ethylene-bridged zwitterionic $[\mathrm{P}] \mathrm{H}^{+} /[\mathrm{B}] \mathrm{CH}_{3}{ }^{-}$compound 9. This was prepared by using an organometallic route that we had recently developed. ${ }^{14}$ We had shown that treatment of $\mathrm{Cp}_{2} \mathrm{Zr}$ $\left(\mathrm{CH}_{3}\right)_{2}$ with the FLP 1 resulted in a clean methyl anion abstraction from the zirconium atom by the active boron Lewis acid to form complex 8. The X-ray crystal structure analysis had confirmed the contact ionic pair structure of compound $\mathbf{8}$ (see Scheme 2). ${ }^{15}$ We have now generated the salt 8 in situ and hydrolyzed it directly without further characterization. Workup eventually gave the new $[\mathrm{P}] \mathrm{H}^{+} /[\mathrm{B}] \mathrm{CH}_{3}{ }^{-}$product 9 as a white solid, which we isolated in $95 \%$ yield.

Compound 9 shows a ${ }^{31} \mathrm{P}$ NMR $[\mathrm{P}]-\mathrm{H}$ resonance at $\delta-2.1$ with a typical large coupling constant of ${ }^{1} J_{\mathrm{PH}} \sim 470 \mathrm{~Hz}$ (the corresponding ${ }^{1} \mathrm{H}$ NMR [P]-H signal is at $\left.\delta 7.36\right)$. The $[\mathrm{B}]-\mathrm{CH}_{3}$ moiety gives rise to a broadened ${ }^{1} \mathrm{H}$ NMR feature at $\delta 0.13\left({ }^{13} \mathrm{C}\right.$ : $\left.\delta 9.4 ;{ }^{11} \mathrm{~B}: \delta-12.7\right)$. As expected, we monitored three ${ }^{19} \mathrm{~F}$ NMR signals of the $o-, p$-, and $m-\mathrm{F}$ atoms of the pair of $\mathrm{C}_{6} \mathrm{~F}_{5}$ groups at boron with a typical small $\Delta \delta^{19} \mathrm{~F}_{m, p}=2.2 \mathrm{ppm}$ chemical shift difference, and we observed the typical ${ }^{1} \mathrm{H} /{ }^{13} \mathrm{C}$ NMR signals of the pair of mesityl substituents at phosphorus and the bridging $-\mathrm{CH}_{2}-\mathrm{CH}_{2}-$ group $\left[{ }^{1} \mathrm{H}: \delta 2.61\left(\mathrm{PCH}_{2}\right), \delta 1.21\left(\mathrm{CH}_{2} \mathrm{~B}\right) ;{ }^{13} \mathrm{C}\right.$ : $\left.\delta 25.0\left({ }^{1} J_{\mathrm{PC}}=34.1 \mathrm{~Hz}\right), \delta 23.0(\mathrm{br} \mathrm{m})\right]$.

The X-ray crystal structure analysis showed the presence of a tetracoordinated boron atom that had the methyl substituent attached to it. The phosphorus atom is protonated $\left(\sum \mathrm{P} 1^{\mathrm{CCC}}\right.$ $343.9^{\circ}$ ) and the central P1-C1-C2-B1 unit shows a close to antiperiplanar conformational arrangement $\left(\begin{array}{ll}\theta & -178.3(3)^{\circ}\end{array}\right)$, whereas the $\mathrm{C} 3-\mathrm{B} 1-\mathrm{C} 2-\mathrm{C} 1$ unit is close to gauche oriented $\left(\theta 64.7(5)^{\circ}\right)$ (see Fig. 3).

We briefly investigated the thermal stability of the compounds 6 and 9. Both turned out to be stable at $60^{\circ} \mathrm{C}$ in dichloromethane solution for prolonged periods of time $(24 \mathrm{~h})$, compound 6 was even stable at $90{ }^{\circ} \mathrm{C}$, whereas compound 9

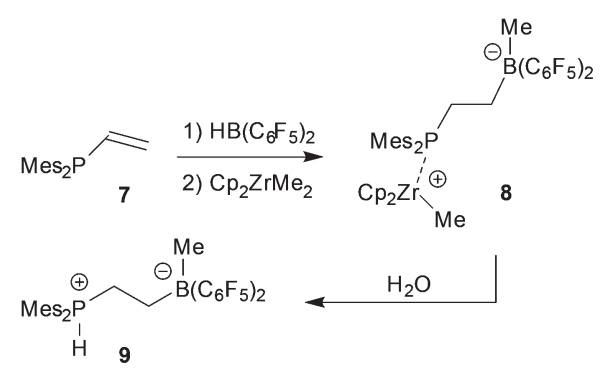

Scheme 2 


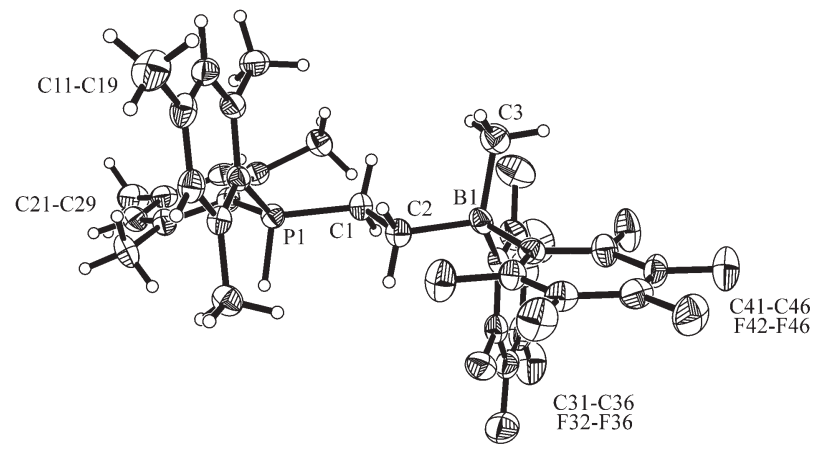

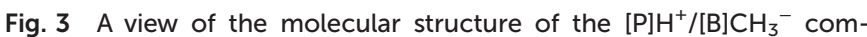
pound 9 (thermal ellipsoids are shown at 30\% probability). Selected bond lengths $(\AA \AA)$ and angles $\left({ }^{\circ}\right)$ : P1-C1 1.796(5), C1-C2 1.528(6), C2-B1 1.658(7), B1-C3 1.646(7), P1-C1-C2 111.7(3), C2-B1-C3 108.0(4), C1C2-B1 110.6(4), $\theta$ H01-P1‥B1-C3 -175.6.

decomposed unspecifically at this temperature (for details and the depicted spectra of these experiments see the ESI $\dagger$ ).

Since our study had shown that both of the formal methane $\mathrm{CH}$ activation products 6 and 9 were stable at $60{ }^{\circ} \mathrm{C}$ in dichloromethane solution, we checked whether $\mathrm{CH}_{4}$ would react with the P/B FLP 1 under these conditions to give either of these two compounds. However, slowly heating of $\mathbf{1}$ in the presence of methane ( $10 \mathrm{bar}$ ) to $60^{\circ} \mathrm{C}$ and keeping the mixture at this temperature for $20 \mathrm{~h}$ did not give any indication of the formation of these products. We only found the usual unspecific decomposition of 1 under these conditions (see the ESI $\dagger$ for details).

The FLP $1 / \mathrm{CH}_{4}$ systems were characterized by DFT analysis. The thermodynamics of the reaction of $\mathbf{1}$ with $\mathrm{CH}_{4}$ were calculated with our established protocol ${ }^{16,17}$ employing PW6B95-D3(BJ)/ def2-QZVP electronic energies. Ro-vibrational free energies from HF-3c harmonic frequencies and solvation free energy corrections for dichloromethane from COSMO-RS(2012 parametrization) were computed at $T=298.15 \mathrm{~K}$.

It turned out that the Gibbs free energies of both reactions were positive, namely $\Delta G(298 \mathrm{~K})=+6.9 \mathrm{kcal} \mathrm{mol}^{-1}$ for the hypothetical $1+\mathrm{CH}_{4}$ to 9 and $\Delta G(298 \mathrm{~K})=+3.6 \mathrm{kcal} \mathrm{mol}^{-1}$ for the $\mathbf{1}+\mathrm{CH}_{4}$ to 6 conversion, i.e. both the methane $\mathrm{C}-\mathrm{H}$ splitting reactions starting from the ethylene-bridged P/B FLP $\mathbf{1}$ are endergonic. Given that the thermodynamically favorable methane liberation is not observed in the experiment, effective kinetic hindrance of the cleavage of $\mathrm{CH}_{4}$ from both 6 and 9 must be assumed. In fact, calculations at the above mentioned level of theory reveal that the barrier $\Delta G^{\ddagger}(298.15 \mathrm{~K})$ for the methane liberation is very high in both cases, being $+72.2 \mathrm{kcal}$ $\mathrm{mol}^{-1}$ for $\mathbf{6}$ and $+54.0 \mathrm{kcal} \mathrm{mol}^{-1}$ for $\mathbf{9}$, respectively (see the $\mathrm{ESI} \dagger$ for details). In both transition states, it is the formally cationic substituent attached to phosphorus which is dissociated and has approached the formally anionic substituent attached to boron. Furthermore, the methane liberation proceeds through inversion of the methyl group, yielding an almost free, planar methyl group (formally a carbocation) in the transition state geometry for the methane liberation from $\mathbf{6}$, while

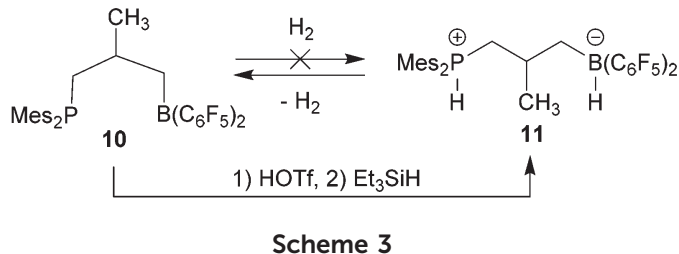

for $\mathbf{9}$, the somewhat planarized methyl group (formally a carbanion) is still close to the boron atom. The presence of the planarized methyl group likely results in the very high barriers. It seems that it is this kinetic protection that essentially makes the pair $\mathbf{6}$ and $\mathbf{9}$ experimentally observable and even isolable under our typical reaction conditions. This is in stark contrast to e.g. the rapid $\mathrm{H}_{2}$ formation from the endergonic $\mathrm{FLP} \mathrm{H}_{2}-$ splitting product $\mathbf{1 1}$ that was in a conceptually related way prepared by an indirect stepwise alternative pathway from the inactive trimethylene-bridged P/B FLP 10 (see Scheme 3). ${ }^{18}$

We might speculate that FLP derived analogues of either 6 or 9 might eventually become available by a methane $\mathrm{CH}$ activation process at much high temperature, taking into account the relatively small endergonic energy amount of these systems. This would, however, require the availability of suited thermally very robust FLPs, systems much more stable than 1 and its congeners. We have just recently reported the beginning of a development towards such robust FLP systems. ${ }^{19}$

Financial support from the Deutsche Forschungsgemeinschaft (grant to G. E. and Leibniz award to S. G.) is gratefully acknowledged.

\section{Notes and references}

1 D. W. Stephan and G. Erker, Angew. Chem., Int. Ed., 2015, 54, 6400 .

2 (a) Frustrated Lewis Pairs I, Uncovering and Understanding, ed. D. W. Stephan and G. Erker, Top. Curr. Chem., Springer, Heidelberg, 2013; (b) Frustrated Lewis Pairs II, Expanding the Scope, ed. D. W. Stephan and G. Erker, Top. Curr. Chem., Springer, Heidelberg, 2013.

3 (a) G. C. Welch, R. R. S. Juan, J. D. Masuda and D. W. Stephan, Science, 2006, 314, 1124; (b) G. C. Welch and D. W. Stephan, J. Am. Chem. Soc., 2007, 129, 1880; (c) P. Spies, G. Erker, G. Kehr, K. Bergander, R. Fröhlich, S. Grimme and D. W. Stephan, Chem. Commun., 2007, 5072.

4 D. W. Stephan and G. Erker, Chem. Sci., 2014, 5, 2625.

5 See e.g.: (a) Y. Hasegawa, G. Kehr, S. Ehrlich, S. Grimme, C. G. Daniliuc and G. Erker, Chem. Sci., 2014, 5, 797; (b) Y. Hasegawa, C. G. Daniliuc, G. Kehr and G. Erker, Angew. Chem., Int. Ed., 2014, 53, 12168; (c) G.-Q. Chen, G. Kehr, C. Mück-Lichtenfeld, C. G. Daniliuc and G. Erker, J. Am. Chem. Soc., 2016, 138, 8554.

6 (a) A. J. P. Cardenas, B. J. Culotta, T. H. Warren, S. Grimme, A. Stute, R. Fröhlich, G. Kehr and G. Erker, Angew. Chem., 
Int. Ed., 2011, 50, 7567; (b) M. Sajid, A. Stute, A. J. P. Cardenas, B. J. Culotta, J. A. M. Hepperle, T. H. Warren, B. Schirmer, S. Grimme, A. Studer, C. G. Daniliuc, R. Fröhlich, J. L. Petersen, G. Kehr and G. Erker, J. Am. Chem. Soc., 2012, 134, 10156; (c) M. Sajid, G. Kehr, T. Wiegand, H. Eckert, C. Schwickert, R. Pöttgen, A. J. P. Cardenas, T. H. Warren, R. Fröhlich, C. G. Daniliuc and G. Erker, J. Am. Chem. Soc., 2013, 135, 8882; (d) J. C. M. Pereira, M. Sajid, G. Kehr, A. M. Wright, B. Schirmer, Z.-W. Qu, S. Grimme, G. Erker and P. C. Ford, J. Am. Chem. Soc., 2014, 136, 513. Review: (e) T. H. Warren and G. Erker, Top. Curr. Chem., 2013, 334, 219.

7 For previous examples of FLP C-H activation reactions see e.g.: (a) G. Ménard and D. W. Stephan, Angew. Chem., Int. Ed., 2012, 51, 4409; (b) E. R. Clark, A. Del Grosso and M. J. Ingleson, Chem. - Eur. J., 2013, 19, 2462; (c) J. Zheng, X. Fan, B. Zhou, Z. H. Li and H. Wang, Chem. Commun., 2016, 52, 4655; (d) K. Chernichenko, M. Lindqvist, B. Kótai, M. Nieger, K. Sorochkina, I. Pápai and T. Repo, J. Am. Chem. Soc., 2016, 138, 4860; (e) M. A. Dureen and D. W. Stephan, J. Am. Chem. Soc., 2009, 131, 8396; (f) C. Jiang, O. Blacque and H. Berke, Organometallics, 2010, 29, 125; (g) D. Winkelhaus, B. Neumann, H.-G. Stammler and N. Mitzel, Dalton Trans., 2012, 41, 9143.

8 For metal-free arene borylation reactions see e.g.: (a) B. E. Carpenter, W. E. Piers, M. Parvez, G. P. A. Yap and S. J. Rettig, Can. J. Chem., 2001, 79, 857; (b) F. Focante, I. Camurati, D. Nanni, R. Leardini and L. Resconi, Organometallics, 2004, 23, 5135; (c) T. S. De Vries, A. Prokofjevs, J. N. Harvey and E. Vedejis, J. Am. Chem. Soc., 2009, 131, 14679; (d) A. Prokofjevs, J. W. Kampf and E. Vedeja, Angew. Chem., Int. Ed., 2011, 50, 2098; (e) M.-A. Légaré, M.-A. Courtemanche, É. Rochette and F.-G. Fontaine, Science, 2015, 349, 513; $(f)$ S. K. Bose and T. B. Marder, Science, 2015, 349, 473; (g) M.-A. Légaré, É. Rochette, J. Légaré Lavergne, N. Bouchard and F.-G. Fontaine, Chem. Commun., 2016, 52, 5387; (h) N. Ishida, T. Moriya, T. Goya and M. Murakami, J. Org. Chem., 2010, 75, 8709; (i) A. Del Grosso, M. D. Helm, S. A. Solomon, D. Caras-Quintero and M. J. Ingleson, Chem. Commun., 2011, 47, 12459; (j) A. Del Grosso, P. J. Singleton, C. A. Muryn and M. J. Ingleson, Angew. Chem., Int. Ed., 2011, 50, 2102; (k) S. A. Solomon, A. Del Grosso, E. R. Clark, V. Bagutski, J. J. W. McDozall and M. J. Ingleson, Organometallics, 2012, 31, 1908; (l) A. Del Grosso, R. G. Pritchard, C. A. Muryn and M. J. Ingleson, Organometallics, 2010, 29, 241. Reviews: $(m)$ T. S. De Vries, A. Prokofjevs and E. Vedejs, Chem. Rev., 2012, 112, 4246; (n) M. J. Ingleson, Topics in Organometallic Chemistry, in Synthesis and Applications of Organoboron Compounds, ed. E. Fernándes and A. Whiting, 2015, vol. 49, p. 39.

9 For examples of metal catalyzed borylation of methane see: (a) A. K. Cook, S. D. Schimler, A. J. Matzger and M. S. Sanford, Science, 2016, 351, 1421; (b) K. T. Smith,
S. Berritt, M. González-Moreiras, S. Ahn, M. R. Smith III, M.-H. Baik and D. Mindiola, Science, 2016, 351, 1424.

10 S. Frömel, R. Fröhlich, C. G. Daniliuc, G. Kehr and G. Erker, Eur. J. Inorg. Chem., 2012, 3774.

11 See for a comparison: R. Roesler, W. E. Piers and M. Parvez, J. Organomet. Chem., 2003, 680, 218.

12 S. Frömel, G. Radermacher, B. Wibbeling, C. G. Daniliuc, T. H. Warren, G. Kehr and G. Erker, Isr. J. Chem., 2015, 55, 210.

13 (a) F. A. Carey and H. S. Tremper, J. Org. Chem., 1969, 34, 4; (b) S. I. Zav'yalov and O. V. Dorofeeva, Izv. Akad. Nauk SSSR, Ser. Khim., 1980, 1634; (c) G. H. Posner and C. Switzer, J. Am. Chem. Soc., 1986, 108, 1239; (d) J. Yu, G. Kehr, C. G. Daniliuc, C. Bannwarth, S. Grimme and G. Erker, Org. Biomol. Chem., 2015, 13, 5783. See for a comparison: (e) D. J. Parks, R. E. von H. Spence and W. E. Piers, Angew. Chem., Int. Ed. Engl., 1995, 34, 809; (f) D. J. Parks, W. E. Piers and G. P. A. Yap, Organometallics, 1998, 17, 5492.

14 S. Frömel, G. Kehr, R. Fröhlich, C. G. Daniliuc and G. Erker, Dalton Trans., 2013, 42, 14531.

15 See for a comparison: (a) R. F. Jordan, Adv. Organomet. Chem., 1991, 32, 325; (b) X. Yang, C. L. Stern and T. J. Marks, Angew. Chem., Int. Ed. Engl., 1992, 31, 1375; (c) X. Yang, C. L. Stern and T. J. Marks, J. Am. Chem. Soc., 1994, 116, 10015; (d) M. Bochmann and S. J. Lancaster, Organometallics, 1994, 13, 2235; (e) H. H. Brintzinger, D. Fischer, R. Mülhaupt, B. Rieger and R. M. Waymouth, Angew. Chem., Int. Ed. Engl., 1995, 34, 1143.

16 (a) R. Ahlrichs, M. Bär, M. Häser, H. Horn and C. Kölmel, Chem. Phys. Lett., 1989, 162, 165-169; (b) TURBOMOLE V7.0.2 2015, a development of University of Karlsruhe and Forschungszentrum Karlsruhe, 1989-2007, TURBOMOLE $\mathrm{GmbH}$, since 2007; available from http://www.turbomole. com.

17 (a) S. Grimme, Chem. - Eur. J., 2012, 18, 9955; (b) Y. Zhao and D. G. Truhlar, J. Phys. Chem. A, 2005, 109, 5656; (c) S. Grimme, J. Antony, S. Ehrlich and H. Krieg, J. Chem. Phys., 2010, 132, 154104; (d) S. Grimme, S. Ehrlich and L. Goerigk, J. Comput. Chem., 2011, 32, 1456; (e) F. Weigend, F. Furche and R. Ahlrichs, J. Chem. Phys., 2003, 119, 12753; $(f)$ F. Weigend and R. Ahlrichs, Phys. Chem. Chem. Phys., 2005, 7, 3297; $(g)$ R. Sure and S. Grimme, J. Comput. Chem., 2013, 34, 1672; (h) F. Eckert and A. Klamt, AIChE J., 2002, 48, 369; (i) A. Klamt, J. Phys. Chem., 1995, 99, 2224; (j) COSMOtherm, Version C3.0, Release 16.01, COSMOlogic $\mathrm{GmbH} \&$ Co. KG, Leverkusen, Germany, 2016.

18 (a) T. Özgün, K.-Y. Ye, C. G. Daniliuc, B. Wibbeling, L. Liu, S. Grimme, G. Kehr and G. Erker, Chem. - Eur. J., 2016, 22, 5988; (b) T. Özgün, K. Bergander, L. Liu, C. G. Daniliuc, S. Grimme, G. Kehr and G. Erker, Chem. - Eur. J., 2016, 22, 11958.

19 G.-Q. Chen, G. Kehr, C. G. Daniliuc, C. Mück-Lichtenfeld and G. Erker, Angew. Chem., Int. Ed., 2016, 55, 5526. 